\title{
The Influence of Working Capital Turnover and Receivable Turnover on Current Ratio at PT. Kalbe Farma Tbk
}

\author{
Amthy Suraya \\ Universitas Pamulang \\ E-mail: $\underline{\text { dosen00627@unpam.ac.id }}$
}

(Received: December-2017; Reviewed: January-2018; Accepted: February-2018;

Avalaibel Online: February-2018; Published: March-2018)

(7) (8) This is an open access article distributed under the Creative Commons Attribution License

EY NC CC-BY-NC-4.0 @2018 by author (https://creativecommons.org/licenses/by-nc/4.0/)

\begin{abstract}
Receivables turnover and working capital turnover are very important for a company. This study aims to determine the Working Capital Turnover and Receivable Turnover has an influence or not on the Current Ratio at PT. Kalbe Farma Tbk during the period 2009-2016. The research method is descriptive and associative using a quantitative approach. This method illustrates the company's financial condition based on real data collected from several sources obtained which are then processed and analyzed so as to obtain a systematic picture and conclusions can be drawn. The coefficient of determination is indicated by the number 0.716 which concluded that the working capital turnover and accounts receivable turnover contributed $71.6 \%$ to the current ratio, while $28.4 \%$ was influenced by other factors not examined. And the results of the $F$ test show that $F_{\text {count }}>F_{\text {table }}(6.303>5.99)$ and significant $(0.043<0.05)$ which means that based on the criteria in the F test the hypothesis is accepted. Then the conclusion is working capital turnover and accounts receivable turnover has a significant effect on the current ratio.
\end{abstract}

Keywords: Working capital turnover; receivables turnover; current ratio

\section{INTRODUCTION}

The development of the business world will cause high competition resulting in increasingly fierce competition between companies (Emik Iriyanti, Nurul Qomariah, 2016; Tambunan, T, \& Arus, 2004). This condition requires every company to always improve and perfect its business fields in order to be able to achieve company goals and maintain the company's survival. Companies in the management and use of owned resources are required to be able to coordinate effectively and efficiently so that the decisions made are appropriate and profitable for the company and for outsiders (Fahmi, 2014; Farid Addy Sumantri et al., 2015; Mangkunegara, 2003; Sudana, 2011).

Accounts receivable turnover and working capital turnover is very important for a company because it is the ratios used in measuring the efficiency of working capital in a company (Diana \& Santoso, 2016; Rahayu \& Susilowibowo, 2014; Sufiana \& Purnawati, 2013; Suminar, 2013). 
The existence of sufficient working capital allows a company to carry out its activities without experiencing difficulties and obstacles that might arise. Determination of the amount of working capital needed by companies varies, one of which depends on the type of company and how big the company is (Atmaja, 2008)(Brigham \& Houston, 2013; Farid Addy Sumantri et al., 2015; Sutrisno, 2013; Syaifuddin, 2008). These capital supply activities are dynamic, so they must keep abreast of company developments. The amount of working capital is one measure that can be used to solve the company's liquidity problems (Faisal, Samben, \& Pattisahusiwa, 2018; Harahap, 2007; Kieso, Weygandt, \& warfield, 2017; Mulyanti \& Supriyani, 2018).

Researchers have observed the financial statements of PT. Kalbe Farma Tbk in particular regarding working capital turnover, accounts receivable turnover, and Current Ratio in the last 8 years. Working Capital Turnover, Receivables Turnover and Current Ratio of PT. Kalbe Farma Tbk can be explained that the Working Capital Turnover of PT. Kalbe Farma Tbk in 2009-2016 experienced a fluctuating condition where there was an increase and decrease. The following are presented in the table below:

Table 1

Working Capital Turnover, Receivables Turnover, and Current Ratio of PT. Kalbe Farma Tbk Period 2009-2016

\begin{tabular}{cccc}
\hline Year & $\begin{array}{c}\text { Working Capital } \\
\text { Turnover (times) }\end{array}$ & $\begin{array}{c}\text { Receivables Turnover } \\
\text { (times) }\end{array}$ & Current Ratio (\%) \\
\hline 2009 & 2,63 & 8,29 & 439,36 \\
2010 & 2,52 & 7,81 & 365,27 \\
2011 & 3,00 & 8,18 & 340,54 \\
2012 & 3,29 & 8,10 & 283,93 \\
2013 & 3,03 & 7,80 & 340,36 \\
2014 & 2,80 & 7,67 & 369,78 \\
2015 & 2,67 & 7,84 & 413,11 \\
2016 & 2,58 & 7,39 & 450,94 \\
\hline
\end{tabular}

Source: www.kalbe.co.id

Liquidity ratios are ratios that illustrate the company's ability to meet short-term obligations (debt). This means that if the company is billed, the company will be able to meet the debt, especially debts that are due (Ernanto, 2018; Fahmi, 2014; Harahap, 2011; Harjito \& Martono, 2008; Kasmir, 2014b). The activity ratio is the ratio used to measure the effectiveness of a company is using its assets. It can also be said that this ratio is used to measure the level of efficiency (effectiveness) in the utilization of company resources (Kasmir, 2014a).

\section{METHOD}

This research is quantitative descriptive, which is to discuss the problems faced by the company with respect to market valuations in financial terms. The population used in this study is all financial statements at PT. Kalbe Farma Tbk. The sample used in the form of financial statements includes a balance sheet and income statement at PT. Kalbe Farma Tbk for the 
period 2009-2016. Data analysis methods used are the descriptive statistic, classical assumption test, multiple linear regression analysis, and hypothesis testing.

\section{RESULT AND DISCUSSION}

This research was conducted at PT. Kalbe Farma Tbk by taking the time period of the calculation of the 2009-2016 financial statements taken only from the balance sheet and income statement. To obtain data and information in writing this thesis which aims to determine the effect of working capital turnover and accounts receivable turnover on current ratio, in this thesis research the research location chosen by the author is PT. Kalbe Farma Tbk, located at KALBE Building Jl. Let Jend Suprapto Kav. 4 Jakarta

\section{Descriptive Statistics Analysis}

Descriptive statistics are statistics used to analyze data by describing or describing data that has been collected as it is without intending to make conclusions that apply to the public or generalizations. From the data of one dependent variable and two independent variables, a descriptive statistical test was tested, then the results obtained according to the following table:

Table 2.

Descriptive Statistics Test Results

\begin{tabular}{lrrrrr}
\hline & N & Minimum & Maximum & Mean & Std Deviation \\
\hline $\begin{array}{l}\text { Working } \\
\text { Capital }\end{array}$ & 8 & 2,52 & 3,29 & 2,8150 &, 26827 \\
$\begin{array}{l}\text { Turnover } \\
\text { Receivables }\end{array}$ & 8 & 7,39 & 8,29 & 7,8850 &, 29360 \\
$\begin{array}{l}\text { Turnover } \\
\text { Current }\end{array}$ & 8 & 283,93 & 450,94 & 375,4113 & 56,26874 \\
$\begin{array}{l}\text { Ratio } \\
\text { Valid N }\end{array}$ & 8 & & & & \\
(Listwise) & & & & & \\
\hline
\end{tabular}

Based on the above table it can be seen that the $\mathrm{N}$ value or the amount of data to be examined is 8 samples or 8 years. Then the minimum and maximum value of working capital turnover is 2.52 and 3.29, accounts receivable turnover is 7.39 and 8.29, and the minimum and maximum current ratio values are 283.93 and 450.94. And the mean value (mean) of the data is the Current Ratio of 375.4113 with a standard deviation of 56.26874, a Working Capital Turnover of 2.8150 with a standard deviation of, 26827, and a Receivable Turnover of 7.8850 with a standard deviation of, 29360.

\section{Classic assumption test}

In the normality test chart analysis, the normal distribution will form one straight diagonal line, and the residual data plotting will be compared with the diagonal line. If the residual data distribution is normal, then the line that will represent the actual data will follow the diagonal line. The following can be displayed in the graph below: 
Figure 1.

Normalitty Test Result

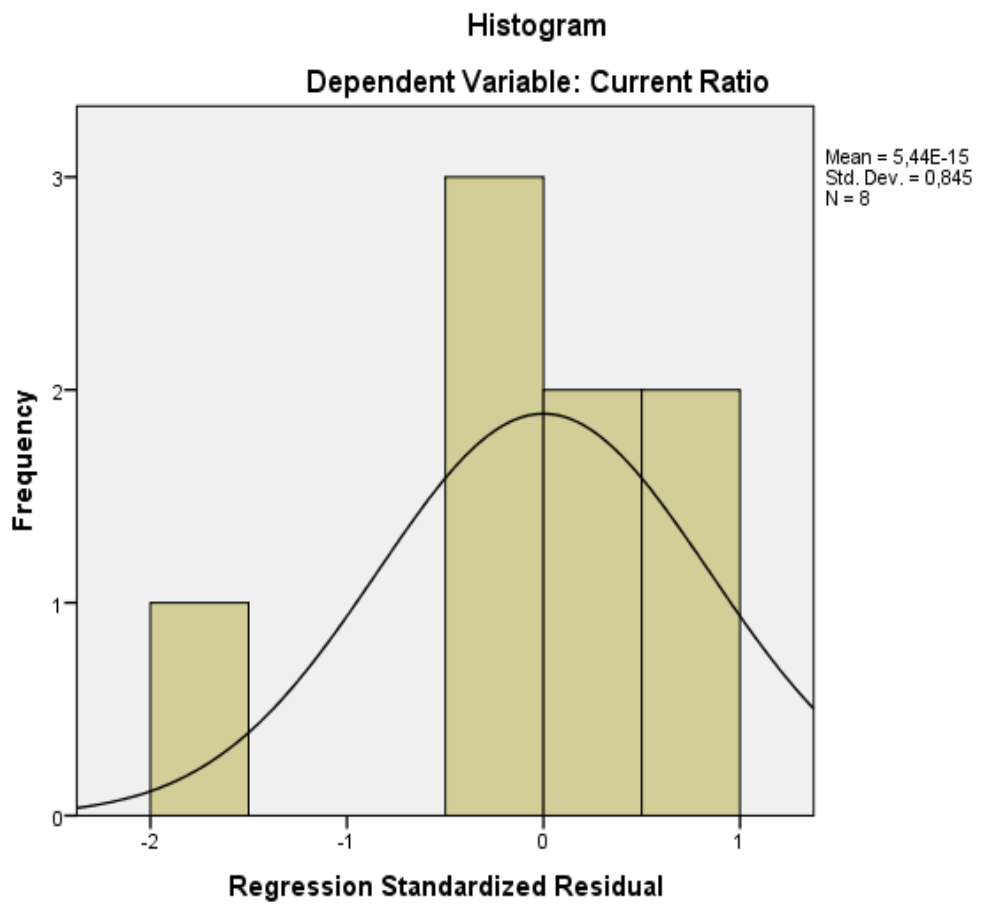

Based on the results of the normality test in this study it can be seen that the histogram graph display shows the normal distribution pattern. This is supported by the image on the normal probability plot with points spread around the diagonal line and the distribution follows the direction of the diagonal line. Thus it can be stated that the spread of data is near normal or meets the assumption of normality.

Table 3.

Multicollinearity Test Result

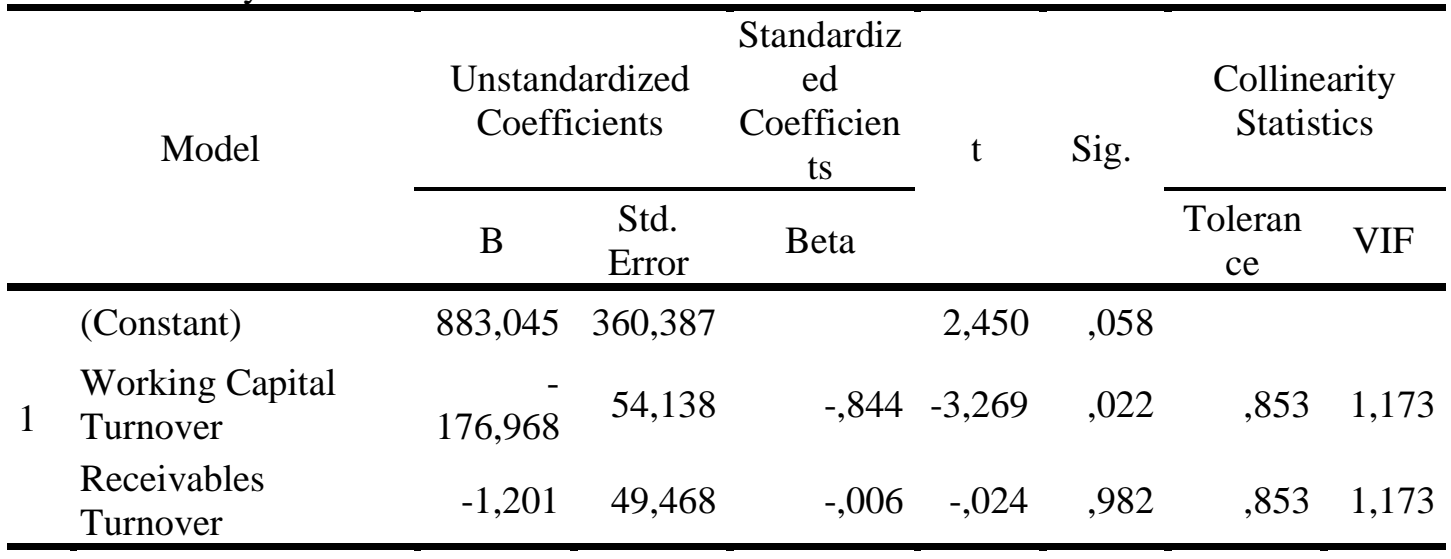

a. Dependent Variable: Current Ratio

In the table above it can be seen that the multicollinearity test variable working capital turnover and receivables turnover has a tolerance value above 0.1 that is equal to 0.853 and a 
VIF value below 10 that is 1.173 so it can be concluded that there is no multicollinearity disturbance between the independent variables.

Figure 2.

Scatterplot Graph

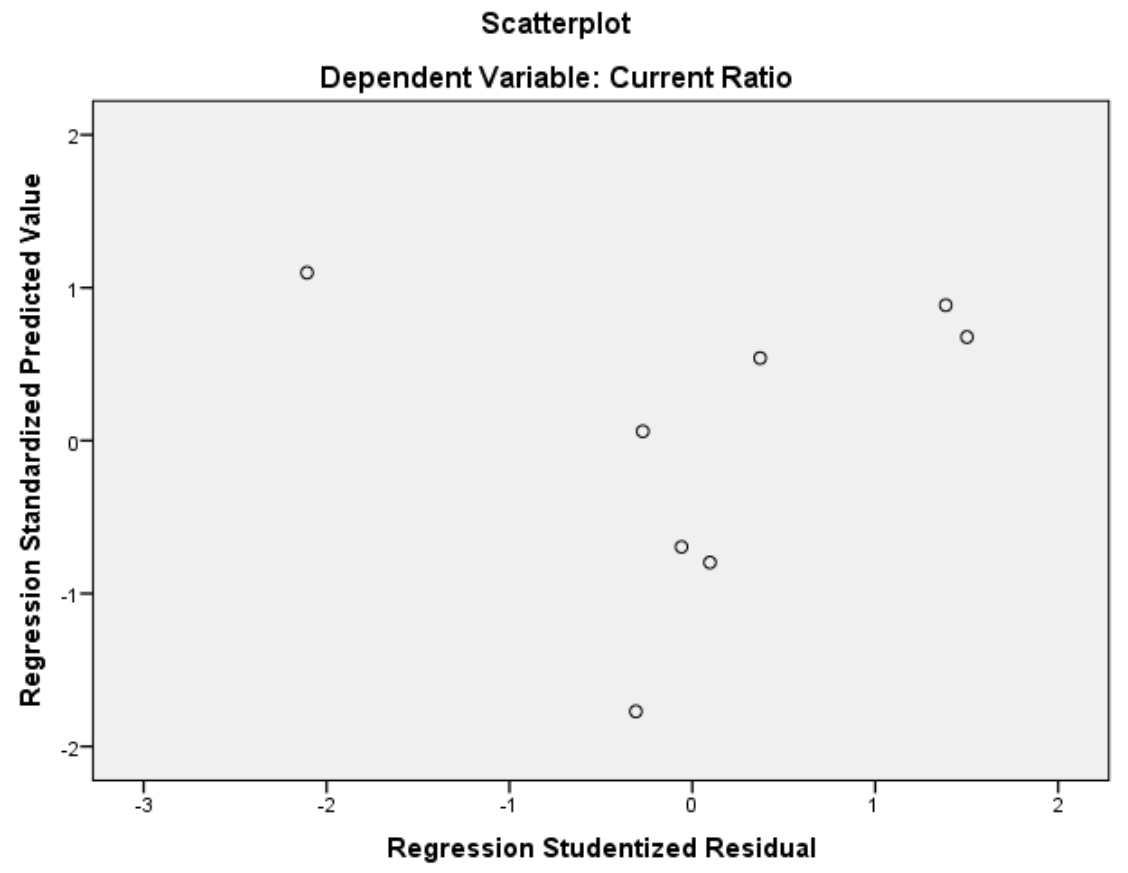

Based on the scatterplot graph of the heteroskedasticity test above, the pattern of the points spreads above and below the number 0 on the $\mathrm{Y}$ axis. It can be concluded that there is no heteroskedasticity. So that the regression model is feasible to be used in research because it has fulfilled the assumptions in the heteroskedasticity test.

Table 4.

Auticorellation Test Result

\begin{tabular}{|c|r|r|r|r|r|}
\hline $\begin{array}{c}\text { Mode } \\
1\end{array}$ & $\mathrm{R}$ & R Square & \multicolumn{1}{|c|}{$\begin{array}{c}\text { Adjusted R } \\
\text { Square }\end{array}$} & $\begin{array}{c}\text { Std. Error of the } \\
\text { Estimate }\end{array}$ & Durbin-Watson \\
\hline 1 &, $846^{\mathrm{a}}$ &, 716 &, 602 & 35,48095 & 2,173 \\
\hline
\end{tabular}

a. Predictors: (Constant), Receivables Turnover, Working Capital Turnover

b. Dependent Variable: Current Ratio

Based on the autocorrelation test results above, it can be seen the value of Durbin Watson (DW) of 2,173 . While DW-table with a significance value of 0.05 or $5 \%$ and the amount of data $(\mathrm{n})=$ 8 , and the independent variable $(k)=2$, the results obtained $d_{L}=0,5591 d_{U}=1,7771,4-d_{U}$ $=2,2229$ and $4-\mathrm{d}_{\mathrm{L}}=3,4409$. Thus the appropriate criteria for the acquisition of autocorrelation test data are the Durbin Watson (DW) value is located at $4-\mathrm{d}_{\mathrm{U}} \leq \mathrm{d}<4-\mathrm{d}_{\mathrm{L}}$ is ,2229 $\leq 2,173<$ 3,4409 these results indicate that there is no autocorrelation. 


\section{Multiple Linear Regression Analysis}

Table 5.

Multiple Linear Regression Analysis Result

\begin{tabular}{|c|c|c|c|c|c|}
\hline \multirow[t]{2}{*}{ Model } & \multicolumn{2}{|c|}{$\begin{array}{l}\text { Unstandardized } \\
\text { Coefficients }\end{array}$} & $\begin{array}{l}\text { Standardized } \\
\text { Coefficients }\end{array}$ & \multirow[t]{2}{*}{$\mathrm{t}$} & \multirow[t]{2}{*}{ Sig. } \\
\hline & B & Std. Error & Beta & & \\
\hline (Constant) & 883,045 & 360,387 & & 2,450 & ,058 \\
\hline $\begin{array}{ll} & \text { Working Capital } \\
1 & \text { Turnover }\end{array}$ & $-176,968$ & 54,138 &,- 844 & $-3,269$ & ,022 \\
\hline $\begin{array}{l}\text { Receivables } \\
\text { Turnover }\end{array}$ & $-1,201$ & 49,468 &,- 006 &,- 024 & ,982 \\
\hline
\end{tabular}

a. Dependent Variable: Current Ratio

Based on the calculation results in the table above we get the form of multiple linear regression equations as follows:

$$
\mathrm{Y}=883,045-176,968-1,201+\mathrm{e}
$$

From the multiple linear regression equation obtained above, a constant value of 883.045 means that if the dependent variable is not influenced by the two independent variables, then the average magnitude of the dependent variable will be worth 883,045 .

The coefficient sign of the independent variable shows the direction of the relationship of the variable concerned with the dependent variable. The regression coefficient for the independent variable is negative, indicating a non-directional relationship between the independent variable and the dependent variable. The variable regression coefficient of 176,968 means that for every change in working capital turnover of one percent will cause a decrease in the current ratio $X_{1}$ of $-176,968 \%$. The regression coefficient for the independent variable $\mathrm{X}_{2}$ is negative, indicating a negative direction regression coefficient, where every change in value, namely the accounts receivable turnover, the current ratio will decrease by $-1,201$.

Based on the table above, it is known that the coefficient of determination of working capital turnover and accounts receivable turnover at the current ratio of 0.716 means that both independent variables have a strong contribution to the dependent variable of $71.6 \%$ while $28.4 \%$ is influenced by variables outside the study. In other words, working capital turnover and accounts receivable turnover are not the only factors that can influence the current ratio, but there are other variables that also contribute to increasing the current ratio. 


\section{Hypotesis Testing}

Table 6.

Hypotesis Testing Result

\begin{tabular}{|r|r|r|r|r|r|r|r|}
\hline \multirow{2}{*}{ Model } & \multicolumn{2}{|c|}{$\begin{array}{c}\text { Unstandardized } \\
\text { Coefficients }\end{array}$} & $\begin{array}{c}\text { Standardize } \\
\mathrm{d} \\
\text { Coefficients }\end{array}$ & \multirow{2}{*}{$\mathrm{t}$} & \multicolumn{2}{|c|}{ Sig. } & \multicolumn{2}{|c|}{$\begin{array}{c}\text { Collinearity } \\
\text { Statistics }\end{array}$} \\
\cline { 2 - 4 } & $\mathrm{B}$ & \multicolumn{1}{|c|}{$\begin{array}{c}\text { Std. } \\
\text { Error }\end{array}$} & Beta & & & Tolerance & VIF \\
\hline $\begin{array}{l}\text { (Constant) } \\
\begin{array}{l}\text { Perputaran } \\
\text { Modal }\end{array}\end{array}$ & 883,045 & 360,387 & & 2,450 &, 058 & & \\
$\begin{array}{l}\text { Kerja } \\
\text { Perputaran } \\
\text { Piutang }\end{array}$ & 176,968 & 54,138 &,- 844 & $-3,269$ &, 022 &, 853 & 1,173 \\
\hline
\end{tabular}

a. Dependent Variable: Current Ratio

From the table above, $t_{\text {hitung }}$ the working capital turnover variable is -3.269 with a significance of 0.022. and $t_{\text {tabel }}$ can be found in the statistical table at a significant 0.05 or $5 \%$ and $\mathrm{df}=\mathrm{n}-\mathrm{k}-$ $1, \mathrm{df}=8-2-1=5$, it is obtained $t_{\text {tabel }}$ at 2.571. It can be seen that $t_{\text {tabel }}>t_{\text {tabel }}(-3,269>2,571)$ and significant $0.05>0.022$ then $\mathrm{H}_{0}$ is rejected and $\mathrm{H}_{1}$ is accepted so that the working capital turnover variable influences the current ratio. Partially the working capital turnover influences the current ratio. This is because the working capital turnover in this study shows the company's ability to meet the needs of funds needed when needed or when debt is due.

From the table above, ${ }^{t_{\text {hitung }}}$ the accounts receivable turnover variable is -0.024 with a significance of 0.982 . and $t_{\text {tabel }}$ can be found in the statistical table at a significant 0.05 or $5 \%$ and $\mathrm{df}=\mathrm{n}-\mathrm{k}-1, \mathrm{df}=8-2-1=5$, it is obtained $t_{\text {tabel }}$ at 2.571 .

It can be seen that $t_{\text {hitung }}<t_{\text {tabel }} \quad(-0,024<2,571)$ and significant $0.05<0.982$ then $\mathrm{H}_{0}$ is accepted and $\mathrm{H}_{1}$ is rejected so that the accounts receivable turnover variable does not affect the current ratio.

Partially accounts receivable turnover does not affect the current ratio. The ineffectiveness of accounts receivable turnover to current ratio is also supported by theoretical logic which states that accounts receivable turnover ratios are calculated by considering credit sales only, and because financial statements rarely disclose cash and credit sales separately, this ratio must often be calculated assuming that insignificant cash sale. So it can be concluded that this causes the assessment of the accounts receivable turnover ratio between years is not reliable in predicting the current ratio. 
Table 7.

F-Test Result

\begin{tabular}{|c|c|c|c|c|c|}
\hline Model & $\begin{array}{l}\text { Sum of } \\
\text { Squares }\end{array}$ & Df & Mean Square & $\mathrm{F}$ & Sig. \\
\hline Regression & 15868,710 & 2 & \multirow{3}{*}{$\begin{array}{l}7934,355 \\
1258,898\end{array}$} & \multirow[t]{3}{*}{6,303} & \multirow[t]{3}{*}{, $043^{b}$} \\
\hline Residual & 6294,490 & 5 & & & \\
\hline Total & 22163,200 & 7 & & & \\
\hline
\end{tabular}

a. Dependent Variable: Current Ratio

b. Predictors: (Constant), Receivables Turnover, Working Capital Turnover

Based on the table above the results $F_{\text {hitung }}$ are 6,303. Then $F_{\text {tabel }}$ it can be searched in the statistical table with a significant $0.05 \mathrm{dfl}=\mathrm{k}-1, \mathrm{df} 1=2-1=1$, and df $2=\mathrm{n}-\mathrm{k}$, df $2=8-2=6$, then obtained $F_{\text {tabel }}=5.99$. From the results of this calculation show that $F_{\text {hitung }}>F_{\text {tabel }}$ (6.303> 5.99) and significant $0.043<0.050$, then based on the test criteria in the $F$ test the results $H_{0}$ are rejected and accepted so that the working capital turnover and accounts receivable turnover have a significant effect on the current ratio.

Simultaneously working capital turnover and accounts receivable turnover have a significant effect on the current ratio. Every time there is a decrease in working capital turnover and accounts receivable turnover simultaneously there is an increase in the current ratio. This is because working capital turnover shows the company's ability to meet the necessary funding needs when needed or when debt is due. And so is the cycle.

Accounts receivable shows the company's ability to collect receivables and convert them into cash so that they can be used by companies to pay their debts. Thus, both variables have a significant simultaneous effect on the current ratio.

\section{CONCLUSION}

Based on the research results, working capital turnover significantly influences the current ratio. Receivables turnover does not affect the current ratio. Working capital turnover and accounts receivable turnover have a significant effect on the current ratio..

\section{REFERENCES}

Atmaja, L. (2008). Teori dan Praktek Manajemen Keuangan. In Yogyakarta: ANDI.

Brigham, E. F., \& Houston, J. F. (2013). Dasar-Dasar Manajemen Keuangan. Salemba Empat. https://doi.org/10.1145/2505515.2507827

Diana, P. A., \& Santoso, B. H. (2016). Pengaruh Perputaran Kas, Piutang, Persediaan Terhadap Profitabilitas Pada Perusahaan Semen Di BEI. Jurnal Ilmu dan Riset Manajemen.

Emik Iriyanti, Nurul Qomariah, A. S. (2016). Pengaruh Harga, Kualitas Produk Dan Lokasi Terhadap Loyalitas Pelanggan Melalui Kepuasan Sebagai Variabel Intervening Pada Depot Mie Pangsit Jember. Jurnal Manajemen Dan Bisnis Indonesia. 
Ernanto, F. N. Q. (2018). Manajemen keuangan publik. Jurnal Kementrian Keuangan.

Fahmi, I. (2014). Manajemen Keuangan Perusahaan dan Pasar Modal. Manajemen Keuangan Perusahaan dan Pasar Modal.

Faisal, A., Samben, R., \& Pattisahusiwa, S. (2018). Analisis kinerja keuangan. KINERJA. https://doi.org/10.29264/jkin.v14i1.2444

Farid Addy Sumantri, Nila, K., Fenti, H., Hery, Sugiyono, Aditya Setiawan, I. P. D., ... Pudjiastuti, S. H. dan E. (2015). Manajemen Keuangan Perusahaan. In Jurnal Ekonomi dan Bisnis. https://doi.org/10.24843/ejmunud.2018.v07.i05.p01

Harahap, S. S. (2007). Analisis Krirtis Atas Laporan Keuangan. Jakarta: PT.Raja Grasindo Persada.

Harahap, S. S. (2011). Teori Akuntansi Edisi Revisi 2011. In Rajawali Pers. https://doi.org/www.rajagrafindo.com

Harjito, D. ., \& Martono, S. . (2008). Manajemen keuangan edisi 2. In Ekonisia.

Kasmir. (2014a). Bank dan Lembaga Kuangan Lainnya. In PT. Raja Grafindo Persada jakarta.

Kasmir. (2014b). Laporan Keuangan Bank. Manajemen Perbankan.

Kieso, Weygandt, \& warfield. (2017). Akuntansi Keuangan Menengah Intermediate Accounting. Salemba Empat.

Mangkunegara, A. A. A. P. (2003). Manajemen Sumber Daya Manusia Perusahaan. In Remaja Rosdakarya. https://doi.org/10.1038/cddis.2011.1

Mulyanti, D., \& Supriyani, R. L. (2018). Pengaruh Perputaran Kas dan Perputaran Persediaan Terhadap Likuiditas pada PT Ultra Jaya, Tbk. Jurnal Kajian Ilmiah. https://doi.org/10.31599/jki.v18i1.180

Rahayu, E. ayu, \& Susilowibowo, J. (2014). Pengaruh Perputaran Kas, Perputaran Piutang dan Perputaran Persediaan Terhadap Profitabilitas Perusahaan Manufaktur. Jurnal Ilmu Manajemen.

Sudana, I. M. (2011). Manajemen Keuangan Perusahaan Teori \& Praktik. In Erlangga. https://doi.org/10.1145/2505515.2507827

Sufiana, N., \& Purnawati, N. (2013). Pengaruh Perputaran Kas, Perputaran Piutang dan Perputaran Persediaan Terhadap Profitabilitas. E-Jurnal Manajemen Universitas Udayana.

Suminar, M. T. (2013). Pengaruh Perputaran Persediaan, Perputaran Piutang Dan Perputaran Kas Terhadap Profitabilitas Pada Perusahaan Sektor Industri Barang Konsumsi Yang Terdaftar Di Bei Periode 2008-2013. Jurnal UNPAD.

Sutrisno. (2013). Manajemen Keuangan Teori Konsep dan Aplikasi. In Manajemen Keuangan Teori Konsep dan Aplikasi.

Syaifuddin. (2008). Manajemen Keuangan (Teori dan aplikasi). 2008. https://doi.org/10.1017/CBO9781107415324.004

Tambunan, T. T., T, D. N. S., \& Arus, A. (2004). Kajian Persaingan Dalam Industri Retail. Kajian Persaingan Dalam Industri Ritel. 